\title{
ROLE OF MATUA PRAIRIE GRASS IN AN ALL-GRASS SYSTEM FOR PRIME LAMB PRODUCTION
}

T.J. FRASER

Grasslands Division, DSIR, Lincoln

Abstract

On light soil in Canterbury, a Nui ryegrass/Matua prairie grass (area proportion 70:30) irrigated farmlet stocked with 20 Coopworth ewes plus 5 ewe hoggets/ha grew 15.0 t DM/ha. From $190 \%$ survival-to-sale of lambs, mean lamb live-weight was $30.6 \mathrm{~kg}$ to give a calculated meat yield of $550 \mathrm{~kg} / \mathrm{ha}$. Ewe replacments grew to $59 \mathrm{~kg}$ in their second summer.

On the same site in a later year and comparing Nui/Matua (area proportion 50:50) with Nui only farmlets at stocking rates of 13 and 16 Coopworth ewes/ha, the pastures grew 11.2, 11.2, 10.2 and 9.9 t DM/ha respectively. The highest yielding system was Nui/Matua $-16 \mathrm{ewes} / \mathrm{ha}$, where from $181 \%$ survival-to-sale of lambs, mean liveweight was $26.8 \mathrm{~kg}$ to give a calculated meat yield of $375 \mathrm{~kg} / \mathrm{ha}$. Nui alone -16 ewes/ha provided for a calculated meat yield of 326 kishma, with ewes in that system being $3.8 \mathrm{~kg}$ lighter than at their mating time.

The features of Matua were its superior cool-season growth and, under dryland condition, its superior feeding quality in summer. Management was rotational grazing in a ten paddock system with short duration of grazing (about 4 days) for Matua pasture.

Keywords: grazing system, lamb meat production, Lolium perenne, Bromus willdenowii.

\section{INTRODUCTION}

Although earlier research has shown high dry matter yields of prairie grass (Bromos willdenowin) at Lincoln (Watkin 1975) and it had shown promise as an associate with lucerne (Medicago sativa) (O'Connor 1967), no satisfactory management for it had evolved to promote its place in pastoral farming in Canterbury. Interest in the species came from the initial testing of the new variety 'Grasslands Matua' prairie grass showing very high cool season growth in a cutting experiment at Lincoln, when sown either alone and with lucerne (Fraser 1982). Concurrent research being done into the use for prime lamb production of lucerne with annual Tama ryegrass (Lolium multiflorum) as a greenfeed supplement, under both irrigated and dryland conditions, had suggested that a perennial grass with good cool season activity was needed to offset the limitation to autumn supply of feed, as the newly-sown Tama was establishing (Vartha \& Fraser 1978). Accordingly a pasture of Matua with lucerne was included in the above system, but the lucerne in that pasture was not satisfactorily established. With irrigation there was a subsequent ingress of white clover(Trifolium repens) into the Matuaand that pasture remained high-yielding (Fraser 1983). Whilst the then current recommendation was that Matua was best suited to lax grazing i.e. longer spelling between grazings and leaving a long stubble (Rumball 1974), the grazing used for lucerne i.e. longer spelling, intensive, short duration grazing, proved suitable for the Matua/white clover pasture.

The popularity of lucerne for grazing diminished in the late 1970's in part due to blue-green aphid attack, but also reflecting the view that lucerne was a costly crop to sow. All-grass farming was emphasised and the advocacy of controlled grazing systems was bringing the concepts of lucerne grazing management in the use of 
ryegrass. It was decided to investigate the limits of lamb production from irrigated Nui ryegrass pasture, with the aspect of greenfeed production for the late winterearly spring period from either Matua prairie grass or Tama ryegrass. Full details of the production of these comparative systems will be given elsewhere. This paper reports the final development of the Nui/Matua system under irrigation. The design was then changed to compare a Nui/Matua system with a Nui-only system, this comparison being made under dryland conditions. There was a 'bridging' year changing from previous irrigated to the dryland condition and with some resowing. This paper also reports one year of the comparison under dryland conditions.

\section{METHODS}

The pastures were grown on a Templeton silt loam at Lincoln, Canterbury. The irrigated experiment comprised two replicated one-ha farmlets sub-divided equally to ten pastures. Of these, two were sown with Matua and Huia white clover and one with Matua and Pawera red clover (Trifolium pratense), the remainder with Nui and Huia. Stocking was with 20 Coopworth ewes/ha mated to a Coopworth sire. Additionally, 5 ewe hoggets were grazed, separate from the ewes, except during winter. Pastures were rotationally grazed. The duration of grazing on Matua never exceeded 4 days. Matua based pastures were used in particular for grazing in late autumn and was then spelled over winter for late winter early spring grazing. After weaning of lambs in early December, they (and the hoggets separately) were break-fed on Matua in summer.

For the comparison of Nui/Matua with Nui-alone on dryland, two of the pastures in the former system were resown to give a total of five Matua pastures. The pastures of the previous two farmlets were randomly allocated to two systems stocked at either 13 or 16 ewes/ha. Thus the stocking rate was not replicated for the Nui/Matua, Nui-only comparison.

The aim of management in the irrigated system was to schedule feed supplied so that ewes would regain their previous mating weight in 12 months time and to obtain satisfactory growth of the ewe hoggets, and the lambs. Herbage that was occasionally, surplus to grazing requirements was conserved as hay.

As there is not the same certainty of production of herbage from dryland pasture to provide a close equation of feed supply and demand as attained in the irrigated system, two stocking rates were used to encompass the likely range of herbage production. The year reported had more summer rainfall than normal so that the lower stocking rate pastures were undergrazed. Rotational shifts between pastures in the rotation were at the same time for both stocking rates, but differently timed for the pasture-comparisons, except in winter where five Nui pastures on all systems were break grazed over a 70 day period from late May to the end of July. Lambing was early September.

\section{RESULTS AND DISCUSSION}

The irrigated Nui/Matua system in the third year from sowing yielded $15.0 \mathrm{t}$ DM. The mean liveweight change of the ewes was $-1.5 \mathrm{~kg}$ per head; ewe hoggets grew to $59 \mathrm{~kg}$; 'survival-to-sale' of lambs was 190\%; mean liveweight of lambs in early February was $30.6 \mathrm{~kg} ; 92 \%$ of the lambs exceeded $25 \mathrm{~kg}$ liveweight; calculated yield of lamb meat was $550 \mathrm{~kg} / \mathrm{ha}$.

Table 1 shows some advantage to Matuaover Nui pastures for annual dry matter yields, however the seasonal contribution of these is of more importance. Matua contributed more in autumn and summer and most importantly in the early spring period. Figure 1 shows a desired growth pattern for achieving satisfactory growth of ewe lambs through to first mating (solid line) (Binnle 1963). The data for the hoggets conformed to this pattern. 
Table 1: SEASONAL PASTURE YIELD OFFERED TO SHEEP GRAZING NUI AND NUI + MATUA SYSTEMS.

\begin{tabular}{|c|c|c|c|c|c|c|c|c|c|}
\hline \multirow{3}{*}{$\begin{array}{l}\text { Stocklng Rate } 20 \\
\text { Cultlvar/Management } \\
\text { Prooortlon }\end{array}$} & \multicolumn{2}{|l|}{ Irrlgated } & \multicolumn{7}{|c|}{ Dryland } \\
\hline & \multicolumn{2}{|c|}{ ewes + 5 hoggets } & \multicolumn{2}{|c|}{13 ewes } & \multirow[b]{2}{*}{$\begin{array}{l}\text { Nui' } \\
50\end{array}$} & \multirow[b]{2}{*}{$\begin{array}{c}\text { Null } \\
50\end{array}$} & \multicolumn{2}{|c|}{16 ewes } & \multirow[b]{2}{*}{$\begin{array}{c}\text { Nui } \\
50 \\
\end{array}$} \\
\hline & $\begin{array}{cc}\text { Null Matua } \\
70 \quad 30\end{array}$ & $\begin{array}{c}\text { Null } \\
50\end{array}$ & $\begin{array}{c}\text { Matua' } \\
50\end{array}$ & , Null & & & $\begin{array}{l}\text { Matua' } \\
50\end{array}$ & $\begin{array}{l}\mathrm{Null} \\
50\end{array}$ & \\
\hline & & & 1 & & 0.9 & 0.9 & & 0 & 0.8 \\
\hline & 0. & & - & & - & & - & & - \\
\hline Early Sprir & 0. & - & 0.6 & 0 & 0.5 & - & 0.6 & & 0.5 \\
\hline ation & 1 & 1 & 2 & & & 7 & & & \\
\hline ummer & $2.7 \quad 1.7$ & 2. & 1. & . & 1. & 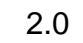 & & & \\
\hline Hay & - & 0.8 & 0.4 & 0.4 & 0.4 & 0.7 & 0.5 & 0.3 & \\
\hline Total system yield ${ }^{3}$ & 15.0 & & 12 & 10. & & & 1.2 & 9.5 & .9 \\
\hline Annual yield ${ }^{3}$ & $\begin{array}{ll}14.1 & 17.2\end{array}$ & 11.2 & 11.1 & 10.7 & 9.7 & 11.5 & $10.9 \quad 1$ & 10.3 & 9.4 \\
\hline
\end{tabular}

1 winter spelled; $40 \%$ of area ploughed in December for renewal.

21 August-5 September

3 tonnes DM/ha

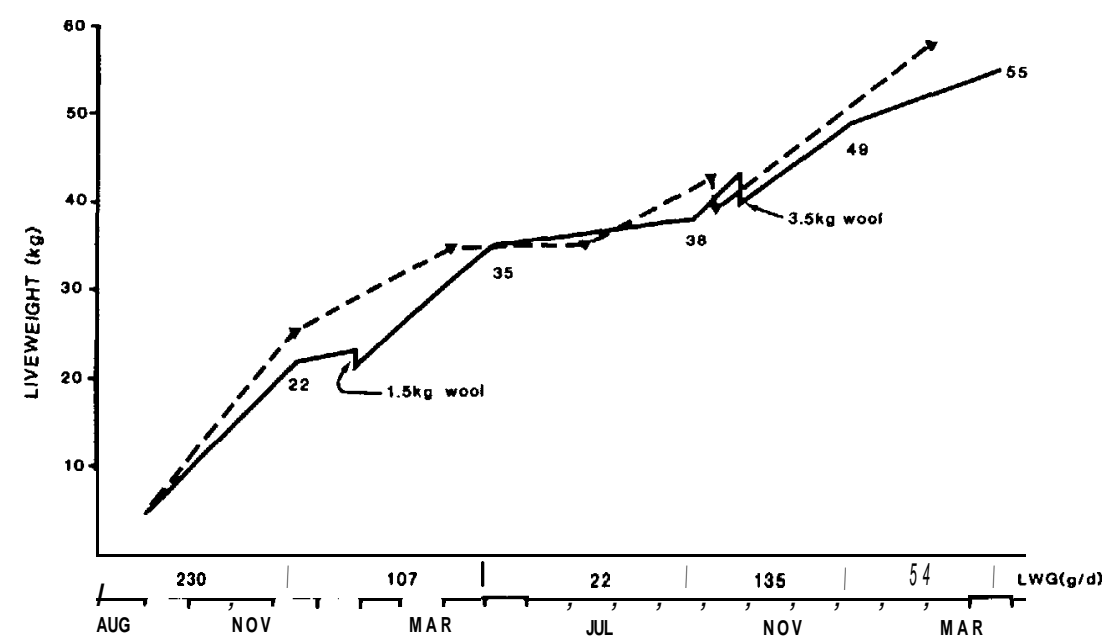

Figure 1: Liveweight gain schedule from birth to first mating of ewes. (solid line = target; broken line $=5$ Coopworth ewe hoggets with 20 mature ewes/ha on NullMatua system).

The chosen proportion of Matua to Nui was such that Matua, which is wintergrowing, was able to be spelled right through winter. Thus winter feeding was on Nui pasture from growth accumulated whilst Matua was being grazed in autumn.

The high production levels in this irrigated experiment reflect a very suitable combination of pasture species, management system and high genetic merit of livestock. Greater concern In Canterbury lies less with maximisation of production on irrigated grassland than with the uncertalnty of production on dryland grassland. The particular problem is growth of pasture in autumn and winter, following summer drought, so as to provide for early spring feeding of livestock. 
In the dryland experiment, to capitalise on the greater growth potential of Matua than of Nui in cool seasons, the chosen proportion of Matua and Nui were evenly balanced. In the year of change-over from irrigated to dryland conditions, despite extremely dry summer conditions, the NuilMatua farmlets yielded 9.5 t DM and Nuionly farmlets 8.2 t. For the year reported, rainfall was higher than this previous year (759 mm March - February cf $539 \mathrm{~mm}$ ) differing in summer by $54 \mathrm{~mm}$. Herbage yields were $11.2 \mathrm{t}$ and $11.2 \mathrm{t}$ DM for NuilMatua at stocking rates of 13 and 18 ewes respectively and $10.2 \mathrm{t}$ and $9.9 \mathrm{t}$ for Nui-only.

Table 1 shows some advantage to Matua/Nul systems in annual herbage provision. The Matua component had greatest impact in autumn and early spring. The lower use of the winter grazed Nui during lactation reflects pastures being conserved as hay. There were two of the winter spelled pastures cultivated on all systems in December reflecting less contribution over this period.

Table 2 shows that only the ewes on Nui high stocking rate were reduced in liveweight; 'survival-to-sale' of lambs was $180-185 \%$ except for $189 \%$ on Nui higher stocking rate; mean liveweight of lambs at mid-January was $26.8 \mathrm{~kg}$ from NuilMatua higher stocking rate with $76 \%$ of lambs exceeding $25 \mathrm{~kg}$. Calculated yield of meat for NuilMatua higher stocking rate was $375 \mathrm{~kg} / \mathrm{ha}$ and for Nui-only higher stocking rate was $328 \mathrm{~kg} / \mathrm{ha}$.

Table 2: ANIMAL PERFORMANCE ON DRYLAND PASTURES

\begin{tabular}{|c|c|c|c|c|}
\hline \multirow[b]{2}{*}{$\begin{array}{l}\text { Ewes } \\
\text { Stocking rate } \\
\text { Ewes start }(\mathrm{kg}) \\
\text { Ewes end }(\mathrm{kg})\end{array}$} & \multicolumn{2}{|c|}{ Nui/Matua } & \multicolumn{2}{|c|}{$\mathrm{Nul}$} \\
\hline & $\begin{array}{c}13 \\
60.5 \pm 1.6 \\
61.2 \pm 1.2\end{array}$ & $\begin{array}{c}16 \\
58.9 \pm 1.0 \\
60.5 \pm 1.1\end{array}$ & $\begin{array}{c}13 \\
60.3 \pm 2.1 \\
59.5 \pm 1.7\end{array}$ & $\begin{array}{c}16 \\
60.9 \pm 2.5 \\
55.7 \pm 1.1\end{array}$ \\
\hline $\begin{array}{l}\text { Lambs } \\
\text { Survival to sale \% } \\
\text { Mean liveweight }(\mathrm{kg}) \\
\text { Calculated meat } \\
\quad \text { yield } \mathrm{kg} / \mathrm{ha}\end{array}$ & $\begin{array}{c}185 \\
25.7 \pm 0.8\end{array}$ & $\begin{array}{c}181 \\
26.8 \pm 0.7\end{array}$ & $\begin{array}{c}185 \\
26.0 \pm 0.8\end{array}$ & $\begin{array}{c}169 \\
25.3 \pm 0.7\end{array}$ \\
\hline
\end{tabular}

The importance of making provision for high quality early spring herbage in an all grass sheep system with a high stocking rate is reflected in the higher animal performance shown for the NuilMatua system in Table 2. At the lower stocking rate there was limited grazing pressure on all pastures at any stage so animal production was similar for both systems.

A feature of the experiment was that Matua pastures were intensively grazed, leaving no measurable residual herbage using hand shears. The annual total of the residual herbage on the Nui pastures of the NuilMatua system was $1.7 \mathrm{t} \mathrm{DM}$ and $1.04 \mathrm{t}$ respectively for lower and higher stocked; that on the Nui-only pastures was respectively 3.36 tand $0.97 \mathrm{t}$. The high residuals of the Nui-only lower stocked pastures would affect their feeding quality, but selective grazing would be possible in them. Performance of weaned lambs on NuilMatua in summer was superior to that on Nui-only even though they were given a lower allowance (Table 3). Ewes gained 2.4 $\mathrm{kg}$ compared to losing $1.5 \mathrm{~kg}$.

Pastures in these experiments to date have lasted for five years in the combined circumstance of irrigated and dryland management. We do not have experience of pasture on dryland entirely for that period. A problem for Matua sown in autumn has been competition from winter growing annual dicotyledonous weeds and annual Poa grass. Research will have to investigate minimum cultivation and direct drilling to overcome this problem. 
Table 3: HERBAGE ALLOWANCE AND LIVEWEIGHT GAIN OF WEANED LAMBS

\begin{tabular}{|c|c|c|c|c|c|c|}
\hline \multirow[b]{2}{*}{$\begin{array}{l}\text { Proportion } \\
\text { Stocking rate }\end{array}$} & \multicolumn{2}{|c|}{ Nui/Matua } & \multirow{2}{*}{$\frac{\text { Nul }}{100}$} & \multicolumn{2}{|c|}{ Nul/Matua } & \multirow{2}{*}{$\frac{\text { Nui }}{100}$} \\
\hline & \multicolumn{2}{|c|}{13} & & 50 & 16 & \\
\hline $\begin{array}{l}\text { Herbage allowance } \\
\mathrm{kg} / \mathrm{lamb} / \mathrm{day}\end{array}$ & \multicolumn{2}{|c|}{1.43} & 2.20 & \multicolumn{2}{|c|}{1.02} & 1.41 \\
\hline $\begin{array}{l}\text { Live weight gain } \\
\text { g/lamb/day }\end{array}$ & & & 126 & & & 118 \\
\hline
\end{tabular}

If Matua can be successfully established on dryland and persist for at least five years, then its attributes of high cool season growth and high quality summer feed provide scope for a considerable improvement in the efficiency of lamb meat production.

\section{ACKNOWLEDGEMENT}

Mr D.M. Moore, Grasslands Division, DSIR, Lincoln for technical assistance.

\section{REFERENCES}

Binnie, D.B. 1983. Animal Industries Workshop, Lincoln College, 33-39.

Fraser, T.J. 1982. N.Z, J. exp. Agric. 70: 235237. 1983. Ibid 11: $297-301$.

O'Connor, K.F. 1967. In: "The Lucerne Crop", Langer R.H.M. ed. Wellington, Reed, $314 \mathrm{pp}$.

Rumball, W. 1974. N.Z. J. exp. Agric. 2: 1.5.

Vartha, E.W.; Fraser, T.J. 1978. Ibid 6: 195-200.

Watkin, B.R. 1975. Proc. N.Z. Grass/d Ass. 36 (Pt 2) 180-190. 